\title{
Non-crop and crop plant diversity and determinants in homegardens of Abay Chomen District, Western Ethiopia
}

\begin{abstract}
Homegarden is one of the potential landuse practices in an agricultural landscape where trees and shrubs are deliberately grown in association with crop production and animal husbandry. The general plant diversity and species composition have been well studied in tropical homegardens. However, the explicit study of plant diversity in terms of different functional groups such as crops and non-crops was poorly addressed. Moreover, how these diversities are mediated by the socio-ecological factors was less understood. Here, we examined the plant diversity in homegardens at three levels, (1) pooled diversity, (2) non-crop diversity and (3) crop diversity. A semi-structured questionnaire was also used to collect data on age, household size and household plant use types in 36 homegardens in June 2017. Along with this data, we have also measured the size of the homegardens and undertook complete plant inventory in these homegardens. The generalized linear model (GLM) was used to analyze the effect of age, household size and households' plant use types on species richness in homegardens. Moreover, one-way ANOVA was employed to test the effect of these factors on the Shannon diversity index of the plant species. The result of the generalized linear model analysis showed that the pooled plant species richness in homegardens increased with increasing the plant use types. The number of non-crop species in homegardens was significantly varied by the households' use types of the plants and the homegarden area. Moreover, the crop species richness increased with increasing households' use types of plants and household family size. Our overall results showed that the diversities of different functional groups were mediated by different socio-ecological factors. In general, our study suggests that explicit examining of plant diversity and the factors that determine these diversities of different functional groups is vital in understanding the role of homegardens in biodiversity conservation.
\end{abstract}

Keywords: agroforestry, diversity, functional diversity, Ethiopia
Volume 2 Issue 5 - 2018

Debissa Lemessa, Abayneh Legesse

Ethiopian Biodiversity Institute, Ethiopia

Correspondence: Abayneh Legesse, Ethiopian Biodiversity Institute, PO Box 30726, Addis Ababa, Ethiopia, Tel +25I 91399957I, Email abunaleg99@gmail.com

Received: February 2I, 2018 | Published: October 04, 2018

\section{Introduction}

Ethiopian is an agrarian country and there are diverse farming practices that include crop production both in fields and in homegardens as a subsistence farming system mainly in highland and midland agroecosystems. ${ }^{1,2}$ Homegardens are one of the landuse practices that involve the deliberate growing of multipurpose trees and shrubs in intimate association with animal and crop production within the compound of individual houses. These tree-crop-animal interactional units areintensively managed by the households. ${ }^{3,4}$

In agricultural landscapes of Ethiopia, homegardens comprise multitude genetic resources and hence can potentially play a considerable role in the conservation of biodiversity that is vital to maintaining the multiple ecosystem functions across spatial scales. ${ }^{5,6}$ Moreover, homegardens provide several services mainly for the farming communities such as food, firewood, fodders, spices, medicinal plants and ornamentals. ${ }^{7,8}$ The number of species growing in farmlands is an important indicator to measure the importance of homegardens for biodiversity conservation in agricultural landscapes. However, from the utility point of view, it is not only the richness that matters but also the multiple services obtained from different functional groups so as to meet the required balanced nutrition and income interest of the households. ${ }^{9,10}$
The homegardens are "islands" in agricultural landscapes and preserve the multifunctionality and which helps for the resilience of the ecosystem at a larger scale. ${ }^{6}$ For example, homegardens are refuges to a high diversity of plant species which are not widely grown in the agroecosystem. ${ }^{11}$ However, there are several ecological, socio-economic and cultural factors that mediate plant species diversity and species composition in homegardens. ${ }^{3,12-15}$ Studies on homegardens have been focusing only on woody species composition and the little explicit study was executed on crop and non-crop plant species diversity in homegardens. Thus, this study attempts to assess the factors that determine the plant diversity (crop and non-crop of plant species) and composition in homegardens of Abay Chomen District, Western Ethiopia.

\section{Materials and methods}

\section{The study Area}

The study area (Figure 1) is located in Abay Chomen district between the geographical coordinates of $9^{\circ} 34^{\prime}-9^{\circ} 36^{\prime} \mathrm{N}$ and $37^{\circ} 18^{\prime}-37^{\circ} 21^{\prime}$ E in Oromia region of West Ethiopia. The study area is characterized by a gentle slope to rugged topography, with an altitudinal range of between $2100-2450 \mathrm{~m}$ a.s.l. The mean annual minimum and maximum temperature range is $18-25^{\circ} \mathrm{C}$. The mean 
annual minimum and maximum rainfall range are 1800-2200mm, document of Abay Chomen agricultural office, 2017). with unimodal rainfall during June to September (unpublished

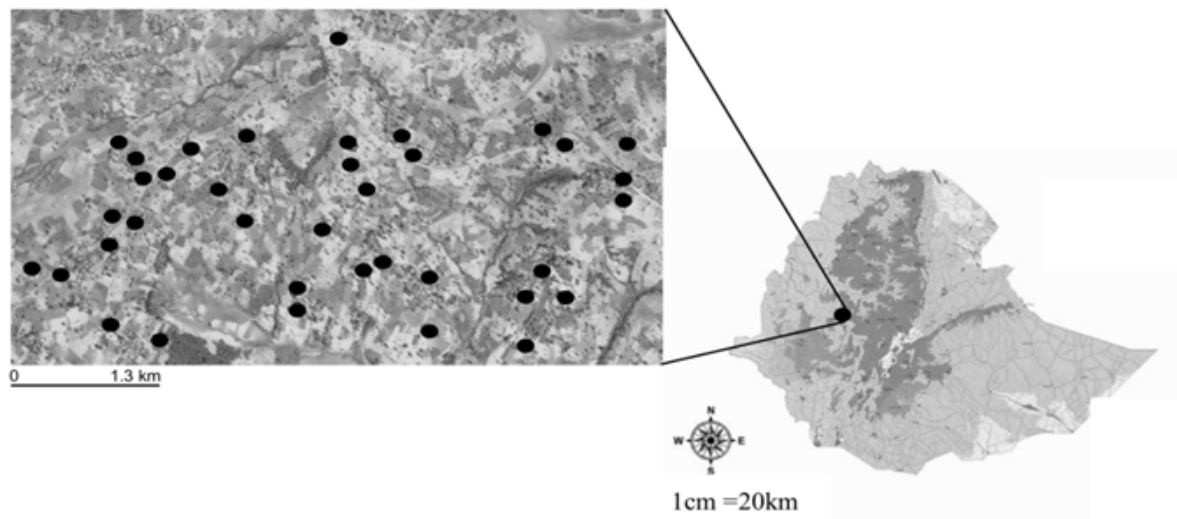

Figure I The map of the study area was produced using satellite image in Google Earth (Image@2017 CNES/Airbus) and shown in relation to the map of Ethiopia. The map also shows the locations of homegardens were shown with GPS points.

The agricultural landscape is characterized as comprising crop land, different sizes of vegetation patches, bush land and scattered trees and shrubs species including Croton macrostachyus, Prunus africana, Cordia africana, Podocarpus falcatus, Eucalyptus sp., Albizia sp., Vernonia sp., Syzygeum guineense, Acacia abyssininca, Oleaeuropea, Rhus sp., Maytenus sp. etc. The farming system in the area is cereal-based for small-scale subsistence. Crop species including teff (Eragrostis teff), maize (Zea mays), wheat (Triticum sp.), barely (Hordeum sp.) pea (Pisum sativum), faba bean (vicia faba), fruits species including mango (Mangifera indica), banana (Musa paradisiaca), papaya (Carica papaya), Casimir (Casimiroa edulis) and Citrus sp., vegetables (onion, potato, carrot and cabbage) and tuber crop including false banana (Ensete ventricosum) are grown in the homegardens for both household consumption and to generate cash income.

\section{Data collection}

To get the overview of the study area and the configuration of homegardens in the landscape, we observed on satellite image in Google Earth (Google Earth, Image $(2017$ CNES/Airbus). With the aid of this satellite image, 36 homegardens were selected for both questionnaire survey and inventory of both non-crop and crop plants (Figure 1). A semi-structured questionnaire was developed to collect data on age, household size, and local name of the plants growing in homegardens and households' plant use types. A complete plant species inventory was performed in 36 homegardens and data were recorded on the type, number and abundance of species in June 2017. The plant specimens were collected, dried and managed following the herbarium techniques. The plant specimens collected were taken to the herbarium of the Ethiopian Biodiversity Institute and were identified by plant taxonomists. Areas of homegardens were measured, excluding areas occupied by the houses. The location (geographical coordinates) of each sample homegarden was recorded with a handheld GPS (Garmin GPSMAP 60CSx) and displayed on satellite image as shown in (Figure 1).

\section{Data analysis}

The Shannon diversity index, which is a widely used index for comparing diversity between various habitats, was calculated for plant species recorded in each homegardens. ${ }^{16}$ The Shannon diversity index was calculated as: $\mathrm{H}^{\prime}=-\sum_{i=1}^{s} p_{i} \ln p_{i}$ where, $\mathrm{H}^{\prime}=$ Shannon Wiener diversity index of the species, $s=$ number of species recorded in each homegarden, $p_{i}=$ Proportion of individuals or the abundance of the $\mathrm{i}^{\text {th }}$ species expressed as a proportion of the total cover and $\ln =\log$ base $_{n}$ (natural logarithm).

Before the data analysis was run, a check was conducted for the normal distribution and homoscedasticity of residuals from plots for species diversity index variable. The plant data were further sorted into non-crop plants including trees and shrubs, and crop plants (i.e., cereals, pulses, vegetables, fruits). Therefore, the analysis was undertaken at three levels, (1) the pooled plant species richness and diversity recorded at homegarden level, (2) non-crop plant species richness, and (3) crop plant species. The plant species diversity index was averaged and hence, the replication was considered at homegardens level. The generalized linear model (GLM) was used to analyze the effect of age, household size and households' plant use types on species richness in homegardens. Moreover, one-way ANOVA was employed to test the effect of these factors on the Shannon diversity index of the plant species recorded in homegardens. For all the analyses R statistical program (version 3.4.0) was used.

\section{Results}

\section{Pooled plant diversity}

Altogether, a total of 93 plant species that belong to 43 families were recorded from the studied homegardens (Table 1). The mean number of plant species (i.e., including both non-crop and crop plants)

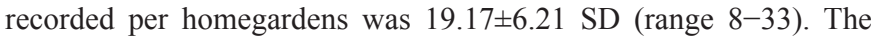
Shannon diversity index (H') varies between $0.69-2.30$ with a mean of $1.73 \pm 0.34 \mathrm{SD}$ per homegarden. From the plant species recorded, the most frequent species occurring in 50\% and above of the homegardens include: Croton macrostachyus, Enset ventricusum, Cuppressus lustanica, Calpurnia aurea, Zea mays, Brassica carinata, Justicia schimperiana, Rhamnus prinoides, Albizia gummifera, Cucurbita pepo, Vernonia amygdalina and Prunus africana. Of these species, Croton macrostachys occurs in all assessed homegardens. The species which rarely occurred, i.e., below $10 \%$ of the homegardens, include: Acacia pilispina, Allophylus abyssinicus, Coccinia abyssinica, Dovyalis abyssinica, Erithrina brucei, Euphorbia abyssinica, Ficus thonningii, Foeniculum vulgare, Hordeium vulgare, Lycopersicum esculentum, Melia azedarach, Osyris quadripartite, Phaseolus vulgaris, Phoenix reclinata, Pisum sativum, Premna scimperi, Rhus glutinosa, Rubus apetalus and Spathodea nilotica. Moreover, the first three most commonly recorded plant families were Fabaceae, Poaceae and Myrtaceae, while the three rare or least plant families recorded were Myrsinaceae, Arecaceae and Santalaceae respectively (Figure 
2 ). The mean households' use type of plants was $5.3 \pm 1.5 \mathrm{SD}$ that ranges from 2-9 use types (Figure 3).

Table I Plant species assessed in the homegardens of the study area

\begin{tabular}{|c|c|c|}
\hline Scientific name & Families & Habitat \\
\hline Acacia pilispina & Fabaceae & Tree \\
\hline Acacia abyssinica & Fabaceae & Tree \\
\hline Acacia decurrens & Fabaceae & Tree \\
\hline Acacia melanoxylon & Fabaceae & Tree \\
\hline Albizia gummifera & Fabaceae & Tree \\
\hline Allium cepa & Alliaceae & Herb \\
\hline Allium porrum & Alliaceae & Herb \\
\hline Allium sativum & Alliaceae & Herb \\
\hline Allopilus abyssinicus & Sapindaceae & Tree \\
\hline Artemisia absinthium & Asteraceae & Herb \\
\hline Arundo donax & Poaceae & Shrub \\
\hline Bersama abyssinica & Melianthaceae & Shrub \\
\hline Beta vulgaris & Chenopodiaceae & Herb \\
\hline Bougainvillea spectabilis & Nyctaginaceae & Liana \\
\hline Brassica carinata & Brassicaceae & Herb \\
\hline Brassica oleraceae & Brassicaceae & Herb \\
\hline Brucea antidysenterica & Simarubaceae & Shrub \\
\hline Buddleja polystachya & Loganiaceae & Shrub \\
\hline Calpurnia aurea & Fabaceae & Shrub \\
\hline Canna indica & Cannaceae & Herb \\
\hline Capsicum annum & Solanaceae & Herb \\
\hline Casimiroa edulis & Rutaceae & Tree \\
\hline Casuarina cunninghamiana & Casuarinaceae & Tree \\
\hline Catha edulis & Celastraceae & Shrub \\
\hline Celtisafricana & Ulmaceae & Tree \\
\hline Chrysopogon zizanioides & Poaceae & Grass \\
\hline Citrus aurantifolia & Rutaceae & Shrub \\
\hline Citrus aurantium & Rutaceae & Shrub \\
\hline Clausena anisata & Rutaceae & Shrub \\
\hline Coccinia abyssinica & Cucurbitaceae & Herb \\
\hline Coffea arabica & Rubiaceae & Shrub \\
\hline Cordia africana & Boraginaceae & Tree \\
\hline Croton macrostachyus & Euphorbiaceae & Tree \\
\hline Cucurbita pepo & Cucurbitaceae & Tree \\
\hline Cuperesses lustanica & Cupressaceace & Tree \\
\hline Cymbopogon citratus. & Poaceae & Grass \\
\hline Daucus carota & Apiaceae & Herb \\
\hline Dodonaea angustifolia & Sapindaceae & Shrub \\
\hline Dovyalis abyssinica & Flacuortiaceae & Shrub \\
\hline Dracaena steudneri & Dracaenaceae & Tree \\
\hline Ekebergia capensis & Meliaceae & Tree \\
\hline Enset ventricusum & Musaceae & Herb \\
\hline Erithrina brucei & Fabaceae & Tree \\
\hline Eucalyptus camandulenses & Myrtaceae & Tree \\
\hline Eucalyptus globulus & Myrtaceae & Tree \\
\hline Euphorbia abyssinica & Myrtaceae & Tree \\
\hline
\end{tabular}

Table Continued.....

\begin{tabular}{|c|c|c|}
\hline Scientific name & Families & Habitat \\
\hline Ficus sur & Moraceae & Tree \\
\hline Ficus thonningii & Moraceae & Tree \\
\hline Ficus vasta & Moraceae & Tree \\
\hline Foeniculumvulgare & Apiaceae & Tree \\
\hline Gravellia robusta & Proteaceae & Tree \\
\hline Guizotia abyssinica & Asteraceae & Tree \\
\hline Hordeium vulgare & Poaceae & Herb \\
\hline Jacaranda mimosifolia & Bignoniaceae & Tree \\
\hline Justicia schimperiana & Acanthaceae & Shrub \\
\hline Lippia adoensis & Verbenaceae & Shrub \\
\hline Lycopersicum esculentum & Solanaceae & Shrub \\
\hline Maesa lanceolata & Myrsinaceae & Shrub \\
\hline Malus sylvesstris & Rosaceae & Shrub \\
\hline Mangifera indica & Anacardiaceae & Tree \\
\hline Maytenus undata & Celastraceae & Tree \\
\hline Melia azedarach & Meliaceae & Tree \\
\hline Millettia ferruginea & Fabaceae & Tree \\
\hline Musa paradisiaca & Musaceae & Herb \\
\hline Nicotiana tabacum & Solanaceae & Shrub \\
\hline Ocimum americanum & Lamiaceae & Herb \\
\hline Ocimum urticifolium & Lamiaceae & Herb \\
\hline Olea europaea subsp cuspidata & Oleaceae & Tree \\
\hline Olinia rochetiana & Penaeaceae & Tree \\
\hline Osyris quadripartita & Santalaceae & Tree \\
\hline Phaseolus vulgaris & Fabaceae & Tree \\
\hline Phoenix reclinata & Arecaceae & Tree \\
\hline Pisdium guajava & Myrtaceae & Tree \\
\hline Pisum sativum & Myrtaceae & Tree \\
\hline Plectranthus edulis & Lamiaceae & Herb \\
\hline Podocarpusfalcatus & Podocarpaceae & Tree \\
\hline Premna scimperi & Verbenaceae & Shrub \\
\hline Prunus africana & Verbenaceae & Tree \\
\hline Rhamnus prinoides & Rhamnaceae & Shrub \\
\hline Rhus glutinosa & Anacardiaceae & Tree \\
\hline Ricinus communis & Euphorbiaceae & Herb \\
\hline Rosa $x$ richardii & Rosaceae & Herb \\
\hline Rosmarinus officinalis & Lamiaceae & Shrub \\
\hline Rubus apetalus & Rutaceae & Liana \\
\hline Ruta chalepensis & Rutaceae & Shrub \\
\hline Schinus molle & Anacardiaceae & Tree \\
\hline Senna petersiana & Fabaceae & Shrub \\
\hline Sesbania sesban & Fabaceae & Tree \\
\hline Solanum tuberosum & Solanaceae & Herb \\
\hline $\begin{array}{l}\text { Spathodea campanulata spp } \\
\text { nilotica }\end{array}$ & Bignoniaceae & Tree \\
\hline Syzygium guineense & Myrtaceae & Tree \\
\hline Vernonia amygdalina & Asteraceae & Shrub \\
\hline Zea mays & Poaceae & Herb \\
\hline
\end{tabular}




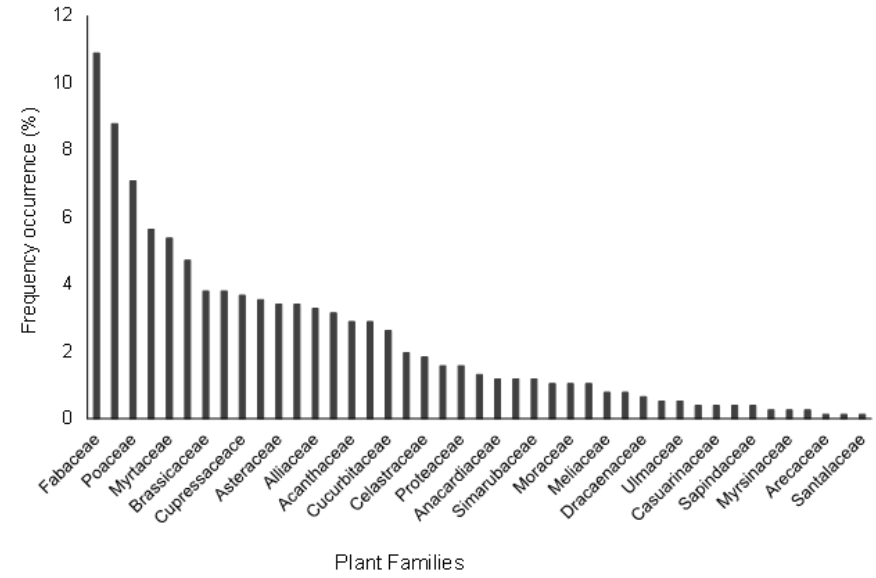

Figure 2 Families of plant species identified in 36 homegardens.

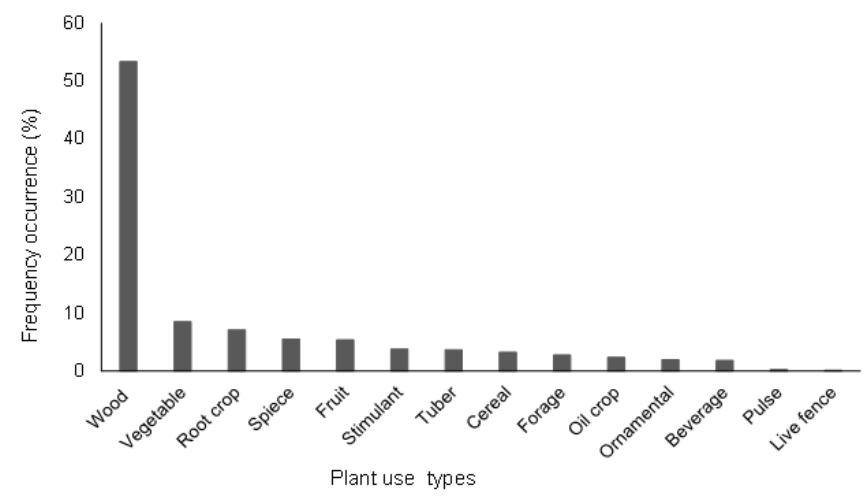

Figure 3 The frequency of plant use types in the homegardens of the study area.

The result of the generalized linear model analysis showed that the plant species richness in homegardens was significantly mediated by the households' use types of the plants $(\mathrm{p}<0.001)$, where the number of species increased with increasing the plant use types (Figure 4). Moreover, the analysis of variance indicated that the Shannon diversity was positively affected by households' use types of the plants $\left(\mathrm{F}_{(1,34)}=\right.$ 9.68, $\mathrm{p}<0.004)$ and the diversity showed increasing pattern with increasing the households' use types of the plants (Figure 5).

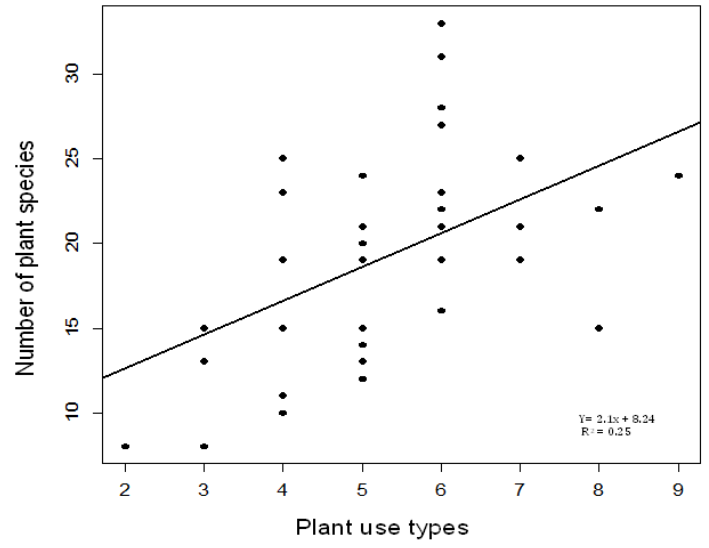

Figure 4 The relationship between households' plant use types and a number of plant species.

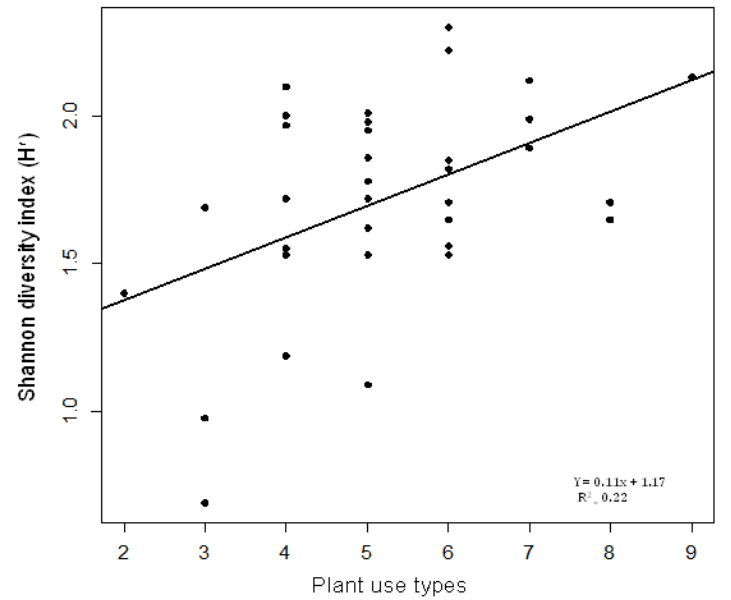

Figure 5 The relationship between households' plant use types and the Shannon diversity index ( $\left.\mathrm{H}^{\prime}\right)$.

\section{Non-crop and crop plant diversity and species richness}

The mean Shannon diversity index (H') for non-crop species was $1.21 \pm 0.95 \mathrm{SD}$ and $1.17 \pm 0.51 \mathrm{SD}$ for crop species, Evenness Index for non-crop species was $0.67 \pm 0.38$ and $0.56 \pm 0.18$ for crop species respectively in the studied homegarden (Table 2).

Table 2 The mean $( \pm S D)$ number of Species richness, diversity and Evenness (Equitability) indices in homegardens $(\mathrm{N}=36)$

\begin{tabular}{llll}
\hline Type $/$ Species & Species richness & Shannon diversity Index & Simpson diversity Index \\
\hline Non-crop & $11.03 \pm 3.48$ & $1.21 \pm 0.95$ & $0.53 \pm 0.33$ \\
Crop & $8.14 \pm 3.84$ & $1.17 \pm 0.51$ & $0.67 \pm 0.38$ \\
\hline
\end{tabular}

\section{Non-crop species richness}

A total of 56 non-crop species were recorded in homegardens and these belong to 35 families. The mean number of non-crop species recorded per homegardens was $11.03 \pm 3.48$ SD (range 4-18). The number of non-crop species in homegardens was significantly dependent on the households' plant use types of the plants $(\mathrm{p}=0.01$, Figure $6 \mathrm{~A})$ and homegarden area $(\mathrm{p}=0.04$, Figure $6 \mathrm{~B})$.

\section{Crop species richness}

A total of 37 crop species were recorded in homegardens and these belong to 18 families. The mean number of crop species recorded per homegardens was $8.14 \pm 3.84 \mathrm{SD}$ (range $0-15$ ). The crop species richness increased with increasing households' plant use types $(p=0.01$, Figure $7 A)$ and household family size $(p=0.03$, Figure $7 B)$. 

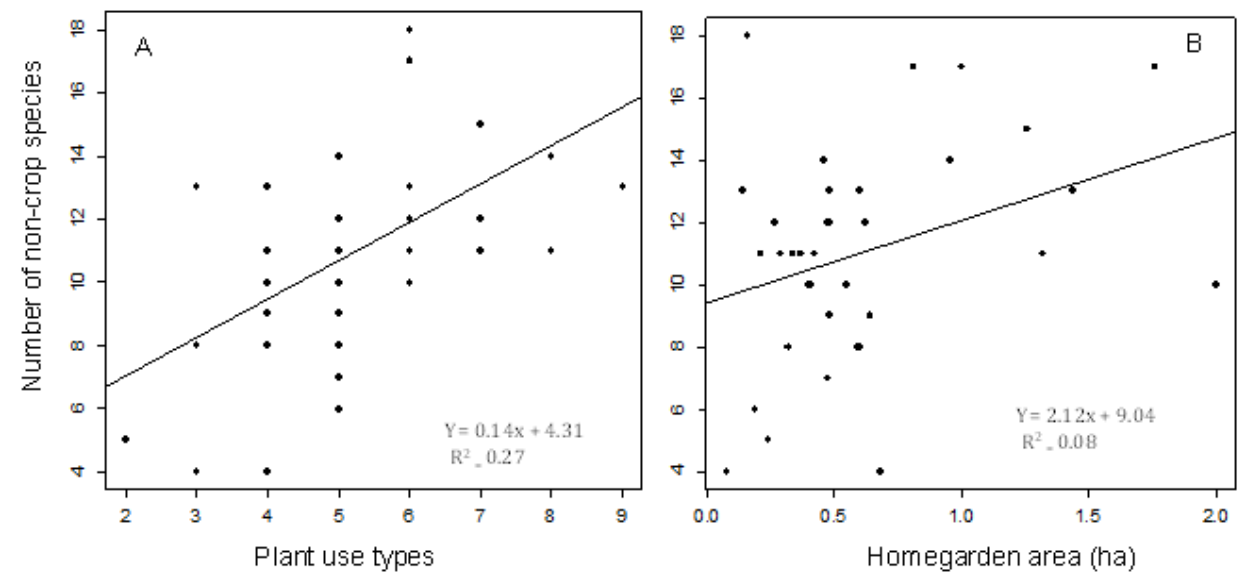

Figure 6 The line graphs show (A) the relationship between households' plant use types and a number of non-crop species, B) the relationship between homegarden area (ha) and number of non-crop species.
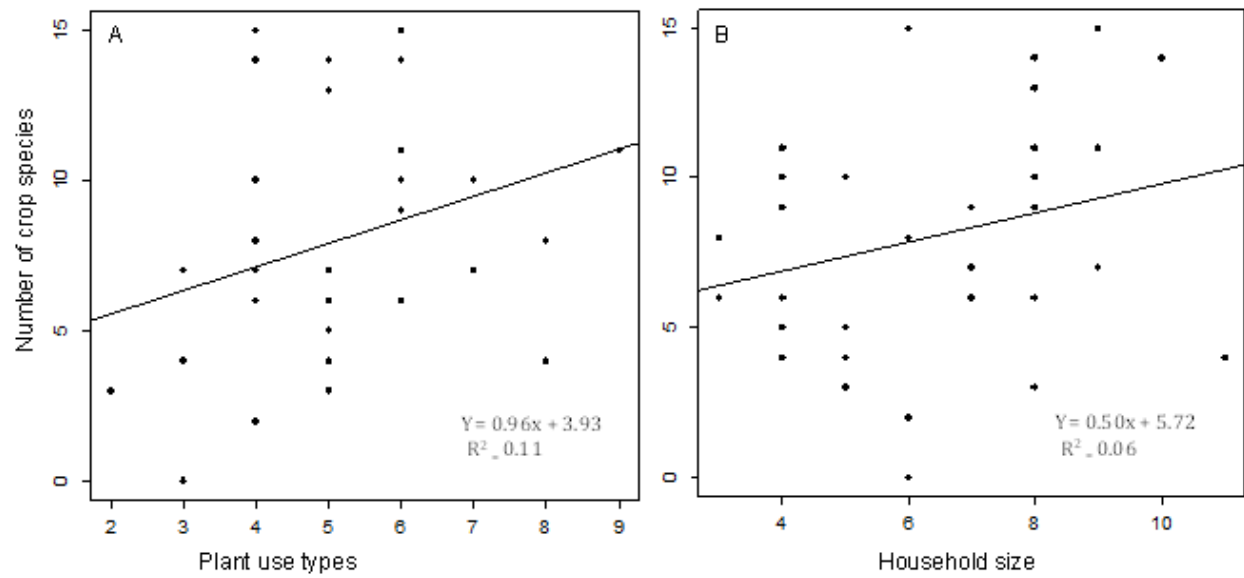

Figure 7 The line graphs show (A) the relationship between households' plant use types and crop species, (B) the relationship between household size and a number of crop species.

\section{Discussion}

\section{Plant species diversity and composition in homegardens}

With the present study, a total of 93 plant species (Table 1) and 14 household' plant use types (Figure 3 ) were recorded in the studied homegardens, out of which 56 were non-crop species and 37 were crop species, which in total belonging to 43 families (Table 1). This result is higher than the findings of ${ }^{17}$ who reported 75 plant species in homegardens of Gedeo Zone, Southern Ethiopia. However, species richness in homegarden of the study area was lower than ${ }^{18}$ that were recorded in Sidama agroforestry (120 plant species) and in homegardens of Wolayta, ${ }^{6}$ Southern Ethiopia (159 plant species). From among the 43 plant families assessed in our study homegardens, Fabaceae was the most dominant one and the most likely reason for this would be that the households' preference is inclined towards growing of leguminous crop and non-crop plant species and medicinal plants in their homegarden. Related to this pattern, several previous studies have also found that farming households grow dominant plant species which belong to the fabaceae family. ${ }^{17,22}$

The mean Shannon index diversity $\left(\mathrm{H}^{\prime}=1.73\right)$ in homegarden of the study area was higher than. ${ }^{18}$ in Enset-Coffee agroforestry systems of the Southern Ethiopia $\left(\mathrm{H}^{\prime}=1.41\right)$ but lower than in homegardens of Dilla Zuriya Woreda, Gedeo Zone, Southern Ethiopia ${ }^{17}$ and in homegarden of Gununo Watershed in Wolayitta Zone, Ethiopia. ${ }^{23}$ The mean values of Evenness (E), as well as Shannon's index, was the highest for the non-crop species. The mean Evenness value for noncrop species was 0.67 and 0.56 for crop species respectively in the homegarden and this indicates that the uniformity in distribution in the composition of species is about $67 \%$ for non-crops and about $56 \%$ for crops.

The different plant life forms of the plant species assessed in the study homegardens were tree, shrub, herb, grass and liana accounting $47.3 \%, 25.8 \%, 22.6 \%, 2.2 \%$ and $2 \%$ respectively. Households use these different plant life forms for different purposes, for example, $53.4 \%$ for wood (construction, fire wood etc.), $8.5 \%$ are vegetable crops, $7.1 \%$ are root crops, $5.5 \%$ are used as spices, $5.51 \%$ used as fruits, $3.81 \%$ as stimulants, $3.67 \%$ used as tuber crops, $3.3 \%$ are cereals, $2.8 \%$ as forage, $2 \%$ are ornamentals, $1.8 \%$ used as beverage, $0.2 \%$ are pulse crops and $0.1 \%$ were as live fences. In this regard, earlier studies have reported similar household use types from different parts of Ethiopia. ${ }^{17,20,24}$ The prsent study has showed that farmers either plant or retain different plant species in their homegardens to fulfill their demands of various products. However, the extent of either retaining or planting of plants in the homegardens depends on the availability of the space, compatibility with agricultural crops and household objectives. For example, our finding has showed that the plant species including Croton macrostachyus, Enset ventricusum, Cuppressus lustanica, Calpurnia aurea, Zea mays, Brassica carinata, Justicia schimperiana, Rhamnus prinoides, Albizia gummifera, 
Cucurbita pepo, Vernonia amygdalina and Prunus africana are the most frequent plant species and found in more than $50 \%$ of the homegardens. Of these species, Croton macrostachys occurs in all assessed 36 homegardens due to its importance for shade, improving soil fertility and positive association or compatibility with food crops.

\section{The plant species diversity variation among homegardens}

Our present study denoted that there is a significant variation in plant species diversity among homegardens and this variation is mainly related to the variation in households' plant use types or multifunctionlity of plants and homegarden area. This pattern may imply that households grow higher number species of crop and noncrop plants based on the multifunctionality of plant species and the area availability in their homegardens. Our finding corporates the earlier study executed in Benin that showed a positive correlation between plant diversity and homegarden area. ${ }^{19}$ Moreover, the species diversity grown by the households may be determined by the household family size indicating the importance of labour availability for growing and managing plants in homegardens either for households own consumption or commercial purpose..$^{18,20}$ The factors that determine the diversity of plant species are, of course, not limited only to these two factors; the households' species preference, ${ }^{6}$ socioeconomic background of the households including wealth status, perception, culture, shortage of seedling and pest problems may influence the extent of plant growing in homegardens and in the surroundings. ${ }^{4,18,21}$

\section{Conclusion}

The positive correlation between Shannon species diversity and households' use types of the plants in homegardens has profound implication for future biodiversity conservation in human modified landscapes. The species richness of non-crop species increased with households' plant use types and homegardens area, while the crop species richness increased with the increasing households' use type of plants and household family size. Homegarden and family sizes found to be the most important determinant factors that affect the diversity of non-crop and crop species respectively. Moreover, homegardens are useful for conservation of biodiversity, and to support the household livelihoods by providing food, income and a wide range of other products such as firewood, fodders, spices, medicinal plants and ornamentals. In general, the further detailed study of explicit examining of plant diversity and the factors like socio-ecological effects that determine these diversities of different functional groups is needed to fully understand the roles of homegardens in biodiversity conservation and in improving human wellbeing.

\section{Acknowledgments}

We would like to extend our great appreciation to Abay Chomen farmers', District and local experts for devoting their precious time to provide us information and sharing their knowledge for this study. We also would like to thank Sisay Alemu, Yayehyirad Teka and Anteneh Shibabaw for their assistance during data collection.

\section{Conflict of interest}

The authors declare that there is no conflict of interest regarding the publication of this article.

\section{References}

1. EBI. Ethiopia's Fifth National Report on the Convention on Biological Diversity, May 2014. Addis Ababa, Ethiopia: Ethiopian Biodiversity Institute; 2014.
2. Lemessa D, Hylander K, Hambäck P. Composition of crops and landuse types in relation to crop raiding pattern at different distances from forests. Agric Ecosyst Environ. 2013;167:71-78.

3. Fernandes EC, Nair PK. An Evolution of the structure and function of tropical homegardens. Agrofor Syst. 1986;21(4):279-310.

4. Kumar BM, Nair PK. The enigma of tropical homegardens. Agrofor Syst. 2004;61(1-3):135-152.

5. Prain G, Fujisaka S, Warren MD. Biological and Cultural diversity: The role of indigenous agricultural experimentation in development. Intermediate Technology Publications, London; 1999.

6. Seta T, Demissew S, Asfaw Z. Home gardens of Wolayta, Southern Ethiopia. An ethnobotanical profile. Acad J Med Plants. 2013;1(1):14-30.

7. Christanty L. Homegardens in Tropical Asia: A special reference to Indonesia. Proceedings of the First International workshop on Tropical Homegarden, Bandung, Indonesia; 1985.

8. FAO. Improving Nutrition through Homegardening: A training package for preparing field workers in Africa. FAO, Rome, Italy; 2001.

9. Zhu Y, Chen H, Fan J, et.al. Genetic Diversity and Disease Control in Rice. Nature. 2000;406(6797):718-722.

10. Abebe T. Determinants of crop diversity and composition in Enset-coffee agroforestry homegardens of Southern Ethiopia. Jarts. 2013;114(1):29 38 .

11. Alexiades M (1996) Collecting ethnobotanical data. An introduction to basic concepts and techniques. In: Alexiades M, Sheldon JW, editors. Selected Guideline for ethnobotanical research. A Field Manual, the New York, Botanical Garden, USA. 1996:58-94.

12. Brownrigg. Home gardening in International development: What the literature shows. League for International Food Education. Washington DC; $1985.55 \mathrm{p}$.

13. Marsh R. Building on Traditional Gardening to improve Household Food Security. Food Nutrition and Agriculture No. 20, Food and Agriculture Organization; 1998.

14. Haileslassie A, Priess JA, Veldkam E, et al. Nutrient flows and balances at the field and farm scale: Exploring effects of land-use strategies and access to resources. Agric Sys. 2007;94(2):459-470.

15. Sydorovych O, Wossink A. The meaning of agricultural sustainability: Evidence from a conjoint choice survey. Agric Sys. 2008;98(1):10-20.

16. Kent M, Kent P, Coker P. Vegetation Description and Analysis: A Practical Approach. London: Belhaven Press; 1992.

17. MengituM, Fitamo D. Plant Species Diversity and Composition of the Homegardens in Dilla Zuriya Woreda, Gedeo Zone, SNNPRS, Ethiopia. Plant. 2015;3(6):80-86.

18. Abebe T. Diversity in homegarden agroforestry systems of Southern Ethiopia. $\mathrm{PhD}$ thesis, Wageningen, The Netherlands: Wageningen University; 2005.

19. Gbedomo RC, Fandohan AB, Salako VK, et.al. Factors affecting home gardens ownership, diversity and structure: a case study from Benin. $J$ Ethnobiol Ethnomed. 2015;11(1):56.

20. Millat-e-Mustafa M. Overview of research in home garden systems. In: Rastogi A, Godbole A, Pei S, editors. Applied Ethnobotany in Natural Resource Management-Traditional Home gardens. International Centre for Integrated Mountain Development, Kathmandu, Nepal, 1998:13-37.

21. Agidie A, Ayele B, Wassie A, et.al. Agroforestry practices and farmers' perception in Koga Watershed, Upper Blue Nile Basin, Ethiopia. Agricult Forest. 2013;59(3):75-89.

22. Kebebew M. Diversity, knowledge and use of medicinal plants in Abay Chomen District, Horo Guduru Wollega Zone, Oromia Region of Ethiopia. J Med Plants Res. 2017;11(31):480-500. 
23. Bajigo A, Tadesse M. Woody Species Diversity of Traditional Agroforestry Practices in Gununo Watershed in Wolayitta Zone, Ethiopia. Forest Res. 2015;4(4):1-7.
24. Khanal S. Contribution of agroforestry in Biodiversity Conservation and Rural Needs Fulfillment. A Study from Lekhnath Municipality and Bharatpokhari VDC of Kaski District. M.Sc. Thesis, Nepal: Tribhuvan University Institute of Forestry; 2011. 127 p. 